\title{
Compensatory Activation of Cannabinoid CB2 Receptor Inhibition of GABA Release in the Rostral Ventromedial Medulla in Inflammatory Pain
}

\author{
ำMing-Hua Li, Katherine L. Suchland, and $₫$ Susan L. Ingram \\ Department of Neurological Surgery, Oregon Health \& Science University, Portland, Oregon 97239
}

\begin{abstract}
The rostral ventromedial medulla (RVM) is a relay in the descending pain modulatory system and an important site of endocannabinoid modulation of pain. Endocannabinoids inhibit GABA release in the RVM, but it is not known whether this effect persists in chronic pain states. In the present studies, persistent inflammation induced by complete Freund's adjuvant (CFA) increased GABAergic miniature IPSCs (mIPSCs). Endocannabinoid activation of cannabinoid (CB1) receptors known to inhibit presynaptic GABA release was significantly reduced in the RVM of CFA-treated rats compared with naive rats. The reduction in CFA-treated rats correlated with decreased CB1 receptor protein expression and function in the RVM. Paradoxically, the nonselective CB1/CB2 receptor agonist WIN55212 inhibited GABAergic mIPSCs in both naive and CFA-treated rats. However, WIN55212 inhibition was reversed by the CB1 receptor antagonist rimonabant in naive rats but not in CFA-treated rats. WIN55212-mediated inhibition in CFA-treated rats was blocked by the CB2 receptor-selective antagonist SR144528, indicating that CB2 receptor function in the RVM is increased during persistent inflammation. Consistent with these results, CB2 receptor agonists AM1241 and GW405833 inhibited GABAergic mIPSC frequency only in CFA-treated rats, and the inhibition was reversed with SR144528. When administered alone, SR144528 and another CB2 receptor-selective antagonist AM630 increased mIPSC frequency in the RVM of CFA-treated rats, indicating that CB2 receptors are tonically activated by endocannabinoids. Our data provide evidence that $\mathrm{CB} 2$ receptor function emerges in the RVM in persistent inflammation and that selective CB2 receptor agonists may be useful for treatment of persistent inflammatory pain.
\end{abstract}

Key words: endocannabinoids; GABAergic transmission; persistent inflammation; RVM; whole-cell patch clamp

Significance Statement

These studies demonstrate that endocannabinoid signaling to $\mathrm{CB} 1$ and $\mathrm{CB} 2$ receptors in adult rostral ventromedial medulla is altered in persistent inflammation. The emergence of $\mathrm{CB} 2$ receptor function in the rostral ventromedial medulla provides additional rationale for the development of CB2 receptor-selective agonists as useful therapeutics for chronic inflammatory pain.

\section{Introduction}

Chronic pain affects $\sim 30 \%$ of the U.S. population (Johannes et al., 2010) and is a significant public health problem. The treatment of chronic pain has been challenging to date for myriad

\footnotetext{
Received April 18, 2016; revised Nov. 29, 2016; accepted Dec. 2, 2016.

Author contributions: M.-H.L. and S.L.I. designed research; M.-H.L. and K.L.S. performed research; M.-H.L. and K.L.S. analyzed data; M.-H.L. and S.L.I. wrote the paper.

This work was supported by National Institutes of Health Grants DA035316 and R56NS093894, and America Heart Association Grant 13SDG14590005 to M.-H.L. RNA quality assessments and qPCR assays were performed in the Oregon Health and Science University Gene Profiling Shared Resource. We thank Drs. Mary Heinricher, Janet Lowe, Laura Kozell, and Qiliang Chen for critical reading of the manuscript; and Dr. Dennis Koop and Lisa Bleyle (Bioanalytical/Pharmacokinetic Core, Oregon Health and Science University) and Dr. Seksiri Arttamangkul (Vollum Institute, Oregon Health and Science University) for technical assistance.

We declare no competing financial interests.

Correspondence should be addressed to Dr. Ming-Hua Li, Department of Neurological Surgery, Oregon Health \& Science University, 3181 SW Sam Jackson Road, Portland, OR 97239. E-mail: limin@ohsu.edu.

DOI:10.1523/JNEUROSCI.1310-16.2016

Copyright $\odot 2017$ the authors $\quad 0270-6474 / 17 / 370626-11 \$ 15.00 / 0$
}

reasons, including ineffective drugs and/or serious side effects with prolonged use of prescribed analgesics (Trang et al., 2015). However, emerging data indicate that drugs that target the endocannabinoid system might produce analgesia with fewer side effects compared with opioids, drugs that are considered to be the gold standard in analgesic treatment (Woodhams et al., 2015).

The endocannabinoid system is comprised of the cannabinoid receptors (CB1 and $\mathrm{CB} 2$ ), endogenous cannabinoid ligands (endocannabinoids) and the enzymes that synthesize and metabolize endogenous ligands to control the bioavailability of endocannabinoids. Endocannabinoids are synthesized in neurons in response to activation of postsynaptic neurons, released and act as retrograde messengers to inhibit presynaptic neurotransmitter release (Kreitzer and Regehr, 2002; Wilson and Nicoll, 2002). CB1 and CB2 receptor inhibitors block endocannabinoid signaling in both central and peripheral sites, promoting and/or prolonging hyperalgesia (Richardson et al., 1997; Calignano et al., 
1998; Meng et al., 1998), indicating that these receptors are potential targets for novel analgesic drugs.

Endocannabinoids are localized throughout the brain and are known to modulate synapses within the descending pain modulatory system that includes the periaqueductal gray (PAG) area and rostral ventromedial medulla (RVM) projections to the spinal cord. This circuit modulates nociceptive transmission pathways during acute injury, as well as induction and maintenance of chronic pain (Ren and Dubner, 2002; Heinricher and Ingram, 2008). Inactivation of the RVM in animal models of neuropathic and inflammatory pain reveals a potent modulation of nociceptive transmission (Burgess et al., 2002; De Felice et al., 2011; Cleary and Heinricher, 2013; Havelin et al., 2016), and persistent inflammation affects the function and activity of RVM neurons (Hurley and Hammond, 2000, 2001; Guan et al., 2002, 2003; Cleary and Heinricher, 2013). Cannabinoid receptor agonists modulate activity of RVM neurons (Meng et al., 1998; Meng and Johansen, 2004), and these effects are reversed with CB1-selective antagonists. CB1 receptor activation decreases GABA release from presynaptic terminals (Vaughan et al., 1999; Atwood et al., 2012). These actions are similar to the cellular actions of opioids in the RVM, except that, in contrast to opioids, cannabinoids do not have postsynaptic effects (Vaughan et al., 1999; Vaughan and Christie, 2005). This difference in cannabinoid and opioid signaling is interesting in that it suggests a differential mechanism of cannabinoid-mediated analgesia compared with opioid-induced modulation of the descending pain pathway. To date, there are few data regarding how the endocannabinoid system in the RVM is regulated in chronic pain states. In addition, the effects of CB2 receptor activation on the descending pain modulatory system are not known, largely due to the fact that $\mathrm{CB} 2$ receptors were thought to be expressed in peripheral tissues. More recent studies provide evidence that $\mathrm{CB} 2$ receptors are expressed in the CNS (for review, see Atwood and Mackie, 2010; Dhopeshwarkar and Mackie, 2014). In addition, analgesic effects of drugs that inhibit degradation of endocannabinoids, thus promoting endocannabinoid actions, are partially reversed with CB2 receptor antagonists (Jayamanne et al., 2006; Anderson et al., 2014). The goal of the present studies was to determine the effects of persistent inflammation on endocannabinoid levels and CB1 and CB2 receptor function in the RVM. Our data show that CB1 receptor function and protein levels are reduced during persistent inflammation without a significant change in endocannabinoid levels. Furthermore, CB2 receptors modulate GABA release in the RVM only in rats pretreated with complete Freud's adjuvant (CFA).

\section{Materials and Methods}

Animals. Male Sprague Dawley rats (Harlan Laboratories and bred inhouse; postnatal day 30-90) were used. All procedures were performed in strict accordance with the Guide for the care and use of laboratory animals as adopted and promulgated by the National Institutes of Health and approved by the Institutional Animal Care and Use Committee of Oregon Health \& Science University.

Persistent inflammation. CFA (heat-killed Mycobacterium tuberculosis in mineral oil, $1 \mathrm{mg} / \mathrm{ml}, 0.1 \mathrm{ml}$ volume injected, Sigma-Aldrich) was injected subcutaneously into the plantar surface of the left hindpaw. The CFA injection produced an intense tissue inflammation of the hindpaw characterized by erythema, edema, and hyperalgesia (Iadarola et al., 1988). Electrophysiological recordings from RVM neurons were made 5-7 d following injections of CFA.

RVM ON-cell labeling. RVM neurons have been previously categorized into $\mu$-opioid-sensitive (presumed ON cells) or $\mu$-opioid insensitive (presumed OFF or NEUTRAL cells) subtypes (Heinricher et al., 2009). A fluorescent opioid compound dermorphin-AlexaFluor-594 (DERM-
A594) was used to label $\mu$-opioid-expressing RVM neurons (Arttamangkul et al., 2006; Phillips et al., 2012; Li et al., 2015). Microinjection of DERM-A594 into RVM was performed as described previously (Li et al., 2015). Briefly, rats were deeply anesthetized with ketamine $(37.5 \mathrm{mg} / \mathrm{kg}) /$ xylazine $(7.5 \mathrm{mg} / \mathrm{kg}) /$ acepramozine $(1.5 \mathrm{mg} / \mathrm{kg})$ mixture (i.p.) and a 23 -gauge stainless steel guide cannula was lowered into the RVM (anteroposterior: -2.1 ; mediolateral: $0.0 \mathrm{~mm}$; dorsoventral: $-7.9 \mathrm{~mm}$ from lambda). A 31-gauge injection cannula that extended $2 \mathrm{~mm}$ beyond the tip of the guide cannula was inserted and DERM-A594 (150-300 ng/0.5 $\mu \mathrm{l}$ in $32 \%$ DMSO and saline) was administered over $100 \mathrm{~s}$. The injection cannula was left in place for an additional $60 \mathrm{~s}$ after injection to minimize backflow up the cannula tract. The injection and guide cannula were removed, and the brain was immediately extracted for electrophysiological recording.

RVM slice preparation. RVM slice preparation was performed as described previously (Li et al., 2015). Rats were deeply anesthetized with isoflurane and the brains were rapidly removed and placed in $\mathrm{N}$-methylD-glucamine-sucrose-based "cutting buffer" containing the following (in $\mathrm{mm}$ ): $52 \mathrm{~N}$-methyl-D-glucamine, $2.5 \mathrm{KCl}, 0.5 \mathrm{CaCl}_{2}, 10 \mathrm{MgSO}_{4}, 1.2$ $\mathrm{NaH}_{2} \mathrm{PO}_{4}, 30 \mathrm{NaHCO}_{3}, 25$ D-dextrose, 75 sucrose, 5 sodium ascorbate, 2 thiourea, 3 sodium pyruvate, $\mathrm{pH} 7.4$, adjusted with $\mathrm{HCl}$ and $300-310$ mOsm (Zhao et al., 2011; Ting et al., 2014). Coronal slices $(180-200 \mu \mathrm{m})$ were cut in $95 \% \mathrm{O}_{2}$ - and $5 \% \mathrm{CO}_{2}$-oxygenated cutting buffer. Slices were incubated at $35^{\circ} \mathrm{C}$ in a submerged chamber containing aCSF equilibrated with $95 \% \mathrm{O}_{2}$ - and 5\% $\mathrm{CO}_{2}$-oxygenated for at least $30 \mathrm{~min}$ and maintained at room temperature afterward until transfer to a recording chamber maintained at $30^{\circ} \mathrm{C}-31^{\circ} \mathrm{C}$. The aCSF contained the following (in mм): $126 \mathrm{NaCl}, 2.5 \mathrm{KCl}, 2.4 \mathrm{CaCl}_{2}, 1.2 \mathrm{MgCl}_{2}, 1.2 \mathrm{NaH}_{2} \mathrm{PO}_{4}, 21.4$ $\mathrm{NaHCO}_{3}, 11.1$ D-dextrose, $\mathrm{pH} 7.4$, and the osmolarity was adjusted to 300-310 mOsm.

Whole-cell patch-clamp recordings. RVM neurons were visualized and labeled with DERM-A594. Voltage-clamp recordings (holding potential $-70 \mathrm{mV}$ ) were made from visually identified RVM ON cells (DERMA594-labeled) or unlabeled cells in the whole-cell configuration using an Axopatch 200B amplifier (Molecular Devices). Patch-clamp electrodes were pulled from borosilicate glass (1.5 mm diameter; WPI) on a twostage puller (PP83, Narishige). Pipettes had a resistance of $2-4 \mathrm{M} \Omega$. IPSCs were recorded in an intracellular pipette solution containing the following (in mM): $140 \mathrm{CsCl}, 10$ HEPES, $4 \mathrm{MgATP}, 3 \mathrm{NaGTP}, 1$ EGTA, $1 \mathrm{MgCl}_{2}$, $0.3 \mathrm{CaCl}_{2}, \mathrm{pH}$ adjusted to 7.3, with $\mathrm{CsOH}, 290 \mathrm{mOsm}$. Series resistance $(<20 \mathrm{M} \Omega)$ was compensated by $70 \%-80 \%$ and continuously monitored during experiments. A junction potential of $-5 \mathrm{mV}$ was corrected during recording. GABAergic events were isolated in the presence of glutamate receptor antagonists, NBQX $(10 \mu \mathrm{M})$ and APV $(50 \mu \mathrm{M})$. Spontaneous miniature IPSCs (mIPSCs) were recorded in the presence of $500 \mathrm{~nm}$ TTX. Events were low-pass filtered at $2 \mathrm{kHz}$ and sampled at $10-20 \mathrm{kHz}$ for on-line and later off-line analysis (Axograph 1.4.3), and individual events were visually confirmed. Recordings in which access resistance or capacitance changed by $>15 \%$ during the experiment were excluded from data analysis. One neuron was recorded per slice, and four or five slices were recorded per rat. Each set of experiments was repeated using at least 3 or 4 distinct rats with no more than 2 cells from a single rat included in a specific dataset.

\section{Liquid chromatography-mass spectrometry analysis of endocannabinoids}

Reagents and chemicals. Silanized glass $13 \times 100 \mathrm{~mm}$ tubes, and siliconized $1.7 \mathrm{ml}$ Eppendorf tubes were from Fisher Scientific, formic acid was from JT Baker, acetonitrile (ACN), methanol, and water were purchased from Burdick and Jackson, trifluoroacetic acid and ammonium acetate were from Sigma-Aldrich, 2-arachidonoylglycerol (2-AG), 1-arachidonoylglycerol (1AG), anandamide (AEA), and 2-arachidonoylglycerol-d5, and anandamide-d4 were from Cayman Chemical.

The analysis of tissue endocannabinoids was developed adapting methods previously described (Richardson et al., 2007; Chen et al., 2009; Zhang et al., 2010). Briefly, RVM slices were weighed and placed into $13 \times 100 \mathrm{~mm}$ screw-top silanized glass tubes, and $100 \mu \mathrm{l}$ of $0.02 \%$ trifluoroacetic acid was added. The slices were sonicated for $30 \mathrm{~s}$ in an ice bath. ACN (4 ml) with $10 \mathrm{ng}$ of 2-arachidonoylglycerol-d5, and $1 \mathrm{ng}$ of 
A

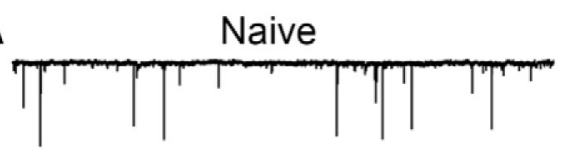

C

\section{Labeled RVM neurons}

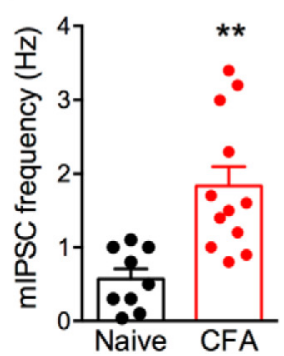

D

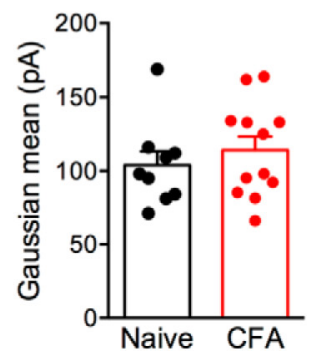

B

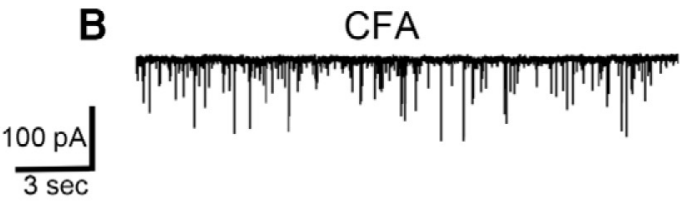
$\frac{100 \mathrm{pA}}{3 \mathrm{sec}}$

E

Unlabeled RVM neurons

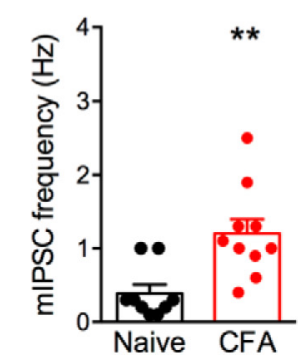

F

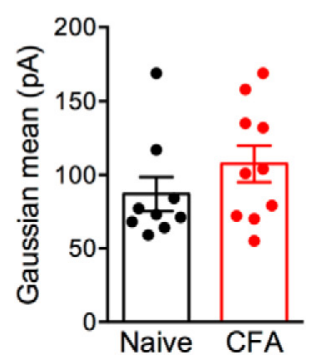

Figure 1. GABA release in the RVM is increased during persistent inflammation. $A$, Representative traces of mIPSCs in RVM slices of naive rats. $\boldsymbol{B}$, Representative traces of mIPSCs in RVM slices of CFA-treated rats. C, D, Summary data of mIPSC frequency and amplitude recorded from DERM-A594-labeled neurons showing that mIPSC frequency is increased in CFA-treated compared with naive RVM (Mann-Whitney, $U=8.50){ }^{* *} p=0.001$ without a change in mIPSC amplitude (unpaired $t$ test, $\left.t(19)=0.75\right), p=0.46 . E, F$, Summary data of mIPSC frequency and amplitude recorded from unlabeled RVM neurons showing that mIPSC frequency is increased in (FA-treated rats compared with naive rats (Mann-Whitney $U=8.0$ ), ${ }^{* *} p=0.001$ without a change in mIPSC amplitude (unpaired $t$ test, $\left.t_{(17)}=1.20\right) \cdot p=0.25$.

A

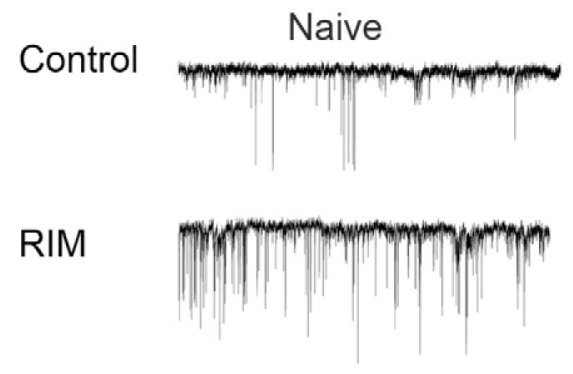

C

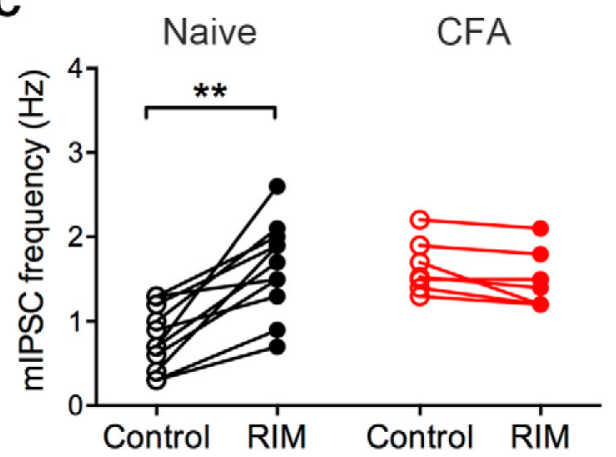

B

$$
\frac{100 \mathrm{pA}}{12 \mathrm{~s}}
$$
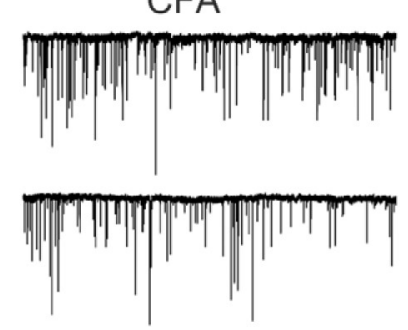

D

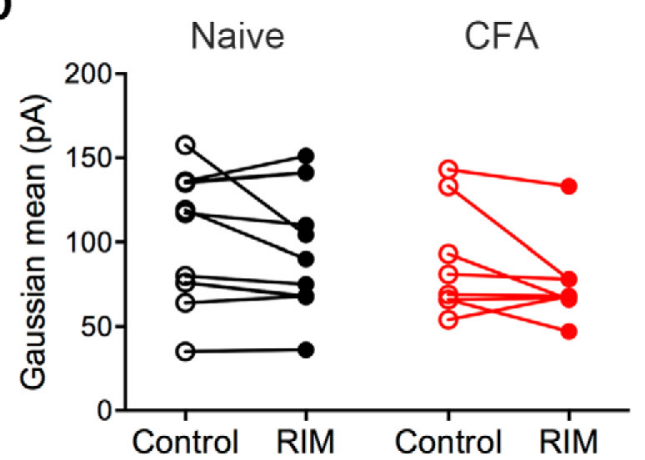

Figure 2. Reduced endocannabinoid inhibition of presynaptic GABA release in persistent inflammation. $A$, Representative traces showing mIPSC frequency in the absence and presence of the CB1 antagonist rimonabant (RIM) in RVM neurons of naive rats. $B$, Representative traces showing mIPSC frequency in the absence and presence of the CB1 antagonist RIM in RVM neurons of CFA-treated animals. C, Summary data showing the increase in mIPSC frequency in the presence of rimonabant recorded from naive RVM neurons (two-way ANOVA, interaction, $\left.F_{(1,17)}=28.66\right) .{ }^{* *} p<0.001 . p<0.01$ (Sidak's multiple comparison). There was no significant change in mIPSC frequency in RVM neurons from CFA-treated rats. $p>0.05$ (Sidak's multiple comparison). D, Mean amplitudes determined from Gaussian fits to mIPSC amplitude histograms were not different in the presence of rimonabant between naive and CFA-treated RVM neurons (two-way ANOVA, interaction, $\left.F_{(1,17)}=0.071\right), p=0.79$.

anandamide-d 4 was added. Samples were then vortex mixed for 5 min at $2500 \mathrm{rpm}$ in a multitube vortexer and then placed on ice for $15 \mathrm{~min}$. Samples were then centrifuged for $15 \mathrm{~min}$ at $4^{\circ} \mathrm{C}$ at $2000 \times g$ to pellet insoluble material. The supernatant was removed to new silanized $13 \times$ $100 \mathrm{~mm}$ culture tube and evaporated to dryness in a speed vacuum evaporator at $35^{\circ} \mathrm{C}$. Dried samples were dissolved in $100 \mu \mathrm{l}$ of ACN, transferred to silanized inserts, and $5 \mu \mathrm{l}$ was injected for analysis. Standards were prepared identically, except there was no tissue present.
Endocannabinoid content was analyzed using a 5500 Q-TRAP hybrid/ triple quadrupole linear ion trap mass spectrometer (Applied Biosystems) with electrospray ionization in positive mode. The mass spectrometer was interfaced to a Shimadzu SIL-20AC XR auto-sampler followed by 2 LC-20AD XR LC pumps. The instrument was operated with the following settings: source voltage $5500 \mathrm{kV}$, GS1 30, GS2 60, CUR 30, TEM 650, and CAD gas medium. Compounds were quantified with multiple reaction monitoring and instrument parameters 
A
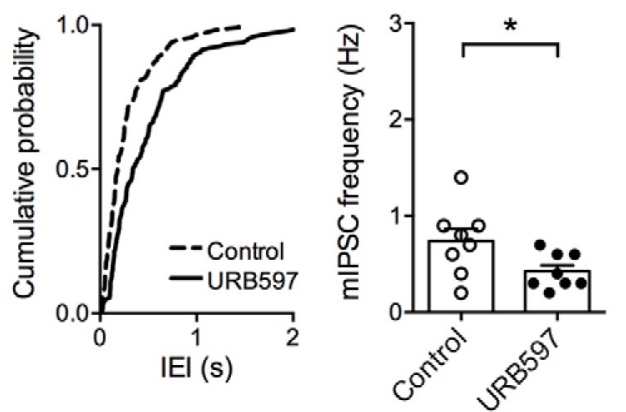

C

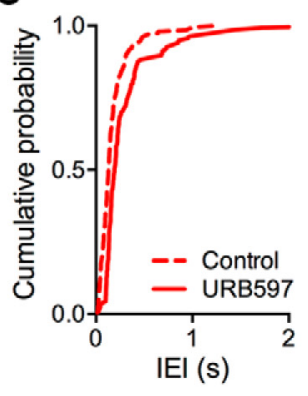

B

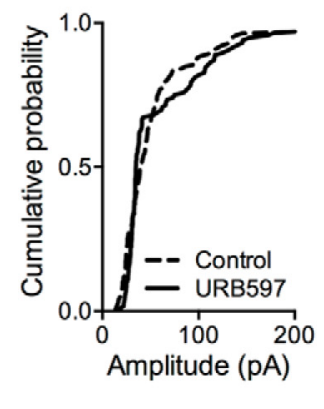

D

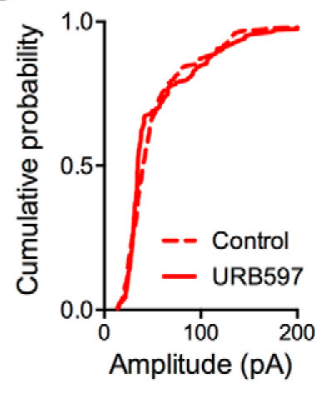

$E$

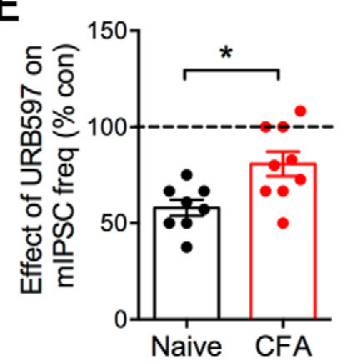

$\mathrm{F}$

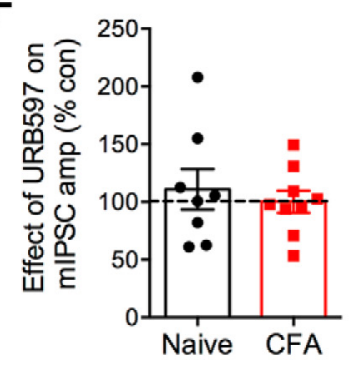

Figure 3. Inhibition of FAAH reduces mIPSC frequency in naive but not CFA-treated rats. A, Cumulative frequency plot and summary data showing that the FAAH inhibitor URB597 increases interevent interval (IEl; left) and decreases mIPSC frequency in naive RVM neurons (right; Wilcoxon matched-pairs signed rank test, $\mathrm{W}=-28$ ). ${ }^{*} p=0.016 . n=8 . \boldsymbol{B}$, There were no significant differences in mIPSC amplitude (paired $t$ test, $\left.t_{(7)}=1.05\right) p=0.33$. C, Cumulative frequency plot and summary data showing that the FAAH inhibitor URB597 has a reduced effect on IEI (left) and mIPSC frequency in RVM neurons from CFA-treated rats (right; Wilcoxon matched-pairs signed rank test, $W=-19) . p=0.063, n=9$. $D$, There were no significant differences in the Gaussian mean of mIPSC amplitude distributions (paired $t$ test, $t_{(8)}=0.48$ ). $p=0.65$. $\boldsymbol{E}$, Summary bar graph comparing the percentage inhibition by URB597 between RVM neurons from naive and (FA-treated rats (unpaired $t$ test, $t_{(15)}=2.91$ ). ${ }^{*} p=0.011 . F$, mIPSC amplitude was not different in the presence of URB597 in naive compared with CFA-treated rats (unpaired $t$ test, $\left.t_{(15)}=0.55\right) \cdot p=0.59$.

for each transition optimized by direct infusion of pure compounds. The $2-\mathrm{AG}$ was monitored using the $[\mathrm{M}+\mathrm{H}]+(\mathrm{m} / \mathrm{z} 379 \rightarrow 287)$ and $\left[\mathrm{M}+\mathrm{NH}_{4}\right]+$ parent ions $(\mathrm{m} / \mathrm{z} 396 \rightarrow 287) .1-\mathrm{AG}$ was monitored as a coeluting peak with the same multiple reaction monitoring transitions as the 2-AG. Other multiple reaction monitoring transitions were as follows: 2 -arachidonoylglycerol-d5, $\mathrm{m} / \mathrm{z} 401 \rightarrow 287$; AEA, m/z $348 \rightarrow 62$; anandamide- $\mathrm{d} 4, \mathrm{~m} / \mathrm{z} 352 \rightarrow 66$. The gradient mobile phase was delivered at a flow rate of $0.3 \mathrm{ml} / \mathrm{min}$ and consisted of two solvents, $\mathrm{A}: 1 \mathrm{~g} / \mathrm{L}$ of ammonium acetate, $0.1 \%$ formic acid in water; and B: $1 \mathrm{~g} / \mathrm{L}$ of ammonium acetate, $0.1 \%$ formic acid in $75 \%$ methanol: $25 \%$ ACN. The initial concentration of solvent B was $45 \%$, which was held for $1 \mathrm{~min}$, followed by a linear increase to $98 \%$ by $11 \mathrm{~min}$, held for $4 \mathrm{~min}$, decreased back to starting $45 \%$ B over $0.1 \mathrm{~min}$, and then held for $7 \mathrm{~min}$, for a total of $22 \mathrm{~min}$. Separation was achieved using a Kinetex $2.6 \mu$ C8 $100 \AA 150 \times 2.1 \mathrm{~mm}$ column (Phenomenex) kept at $45^{\circ} \mathrm{C}$ using a Shimadzu CTO-20AC column oven. Data were acquired using Analyst 1.6.2 and analyzed with Multiquant 3.0.1. Standard curves for the 2-AG were from 1 to $250 \mathrm{ng}$ per slice; AEA was $10-2500$ pg per slice. The relative SD was $<15 \%$ for all concentrations.

Western blot. Rats were injected with CFA in a hindpaw or were left naive to treatment. Brains were collected 5-7 d later, and RVM tissue was microdissected and homogenized in Transmembrane Protein Extraction Reagent (FIVEphoton Biochemicals) with protease inhibitors. After incubating $30 \mathrm{~min}$ on ice, lysates were centrifuged at 13,000 RPM for $10 \mathrm{~min}$ and supernatant was collected. Protein concentration was determined by BCA protein assay (Thermo Scientific). Total protein was incubated at $60^{\circ} \mathrm{C}$ for $10 \mathrm{~min}$ and separated by electrophoresis on precast NuPAGE 4\%-12\% Bis-Tris gels (Invitrogen), then transferred to nitrocellulose membrane. Blots were blocked with $5 \%$ milk $(\mathrm{CB} 1)$ or $3 \%$ BSA (CB2) in PBS-T buffer (10.6 mM NaH $\mathrm{PO}_{4}, 56.5 \mathrm{~mm}$ $\mathrm{Na}_{2} \mathrm{HPO}_{4}, 70 \mathrm{~mm} \mathrm{NaCl}, 0.1 \%$ Tween 20, pH 7.4) at room temperature for $1 \mathrm{~h}$. Blots were then incubated with rabbit CB1-L15 antibody (1:500; generous gift from Dr. Ken Mackie, Indiana University) or rabbit $\mathrm{CB} 2$ antibody (ACR-002, 1:200, Alomone Labs) overnight at $4^{\circ} \mathrm{C}$. Membranes were washed with PBS-T and incubated in goat anti-rabbit secondary antibody for $1 \mathrm{~h}$ at room temperature (Invitrogen; 1:2000). Immunoreactivity was detected using SuperSignal West Pico Chemiluminescent Substrate (Thermo Scientific) and captured using a FluroChem FC2 (AlphaInnotech). Analysis was performed using ImageJ software (National Institutes of Health). CB1 and CB2 receptor bands were analyzed relative to $\beta$-actin bands as a loading control.

Authentication of antibodies. G-proteincoupled receptor antibodies are notoriously nonspecific. The CB1-L15 antibody has been extensively tested using Western blot experiments and detects CB1 receptor bands in the expected range of $49-62 \mathrm{kDa}$ in rat tissue (Grimsey et al., 2008). We analyzed the band at $62 \mathrm{kDa}$. The CB2 antibody recognizes a peptide sequence in the intracellular third loop, and these amino acids (228-242) are identical between rat CB2 and mouse CB2 receptors. Immunostaining was reduced in $\mathrm{CB} 2 \mathrm{KO}$ mice and with preabsorption with the specific immune peptide (Zhang et al., 2014). We confirmed that the band $(40 \mathrm{kDa})$ that we analyzed was reduced with the specific immune peptide in our Western blot experiments. We are still concerned by the fact that we observed multiple bands with both antibodies in the size range expected for CB1 and CB2 receptors (shown in Fig. 4). We also recognize that testing in neither mouse KO models nor preabsorption controls is actually an appropriate control for specificity of antibodies in rat tissue. This is especially a concern for CB2 antibodies (Marchalant et al., 2014). Thus, the lack of change in $\mathrm{CB} 2$ receptor protein levels may indicate that total $\mathrm{CB} 2$ receptor protein is not changed, but there are more functional CB2 receptors on the plasma membrane of terminals in the RVM in CFA-treated rats or that the $\mathrm{CB} 2$ antibody recognizes additional protein(s) in a similar size range that are not altered by CFA treatment.

$q P C R$. Rats were injected with CFA in a hindpaw or were left naive to treatment. Brains were collected 5-7 d later, and RVM tissue was microdissected and flash frozen. RNA was isolated by the Oregon Health \& 
A

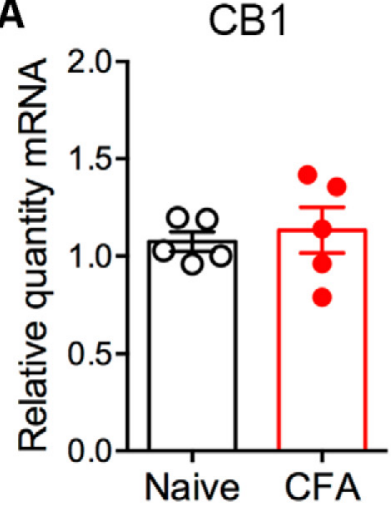

C

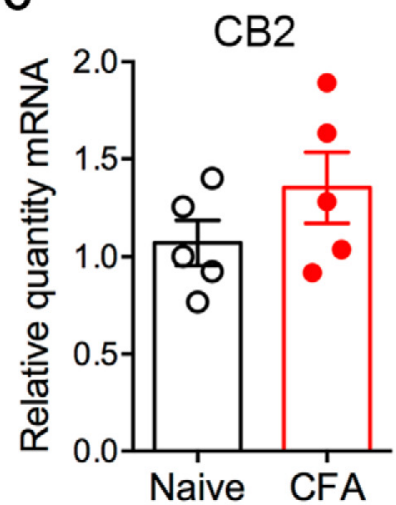

B
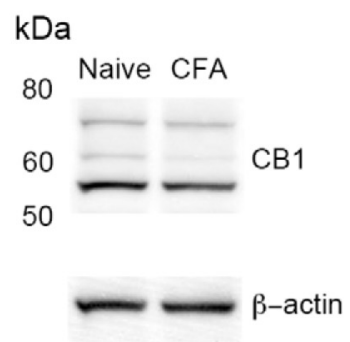

D

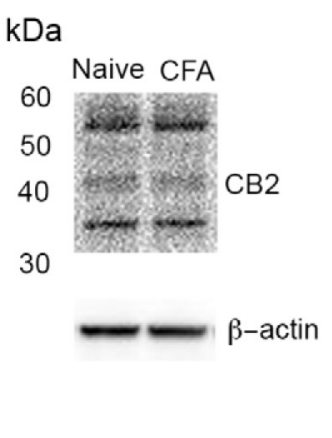

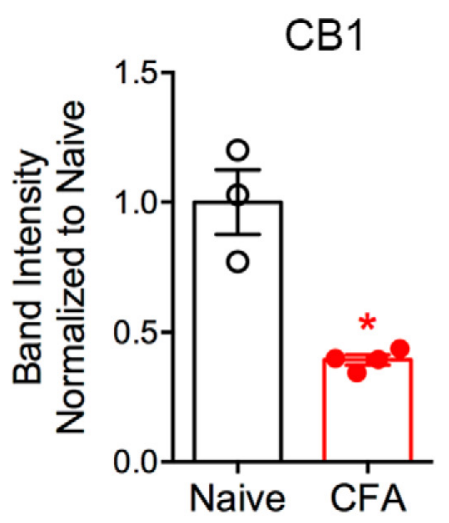

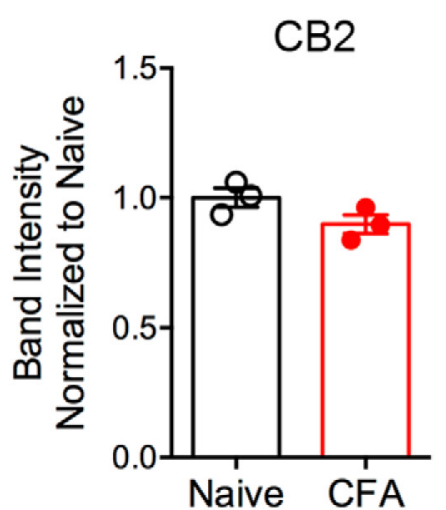

Figure 4. Persistent inflammation does not change $C B 1$ and $C B 2$ mRNA levels but decreases $C B 1$ protein levels. $A$, Relative quantities of mRNA for CB1 receptor expression in the RVM are not changed during persistent inflammation (unpaired $t$ test, $t_{(8)}=1.31$ ). $p=0.6$. Expression levels were compared with mapk6 internal control. $\boldsymbol{B}$, Representative Western blot image and summary data show that the CB1 protein levels for the band running at $62 \mathrm{kDa}$ are reduced in RVM from CFA compared with naive rats (unpaired $t$ test, $\left.t_{(5)}=5.67\right) .{ }^{*} p=0.002 . n=3$ or 4 rats $/$ group. 0 ther bands were not significantly changed $(p>0.05)$. Bands were analyzed relative to $\beta$-actin bands and then normalized to naive. $C$, Relative quantities of $m R N A$ for CB2 receptor expression in the RVM are not changed after $5 \mathrm{~d}$ of inflammation (unpaired $t$ test, $t_{(8)}=0.46$ ). $p=0.66$. D. Representative Western blot image and summary data show that the CB2 protein levels for the band running at $40 \mathrm{kDa}$ were the same for RVM tissue from naive and (FA-treated rats (unpaired $t$ test, $\left.t_{(4)}=2.0\right) . p>0.05 . n=3$ rats/group. Other bands were also not significantly changed $(p>0.05)$. Bands were analyzed relative to $\beta$-actin bands and then normalized to naive.

Science University GPSR Core from tissue using the RNeasy Micro kit (QIAGEN). Following RNA isolation, RNA quality assessment was performed using the Agilent 2100 Bioanalyzer with a Eukaryote total RNA Pico chip. Reverse transcription (RT) was performed using the SuperScript VILO cDNA synthesis kit (Invitrogen) with 750 ng of input RNA per $30 \mu \mathrm{l}$ reaction for mRNA. Following reverse transcription, $2 \mu \mathrm{l}$ of cDNA was used in the PCR using the TaqMan Universal mastermix (Invitrogen). The qPCR assays were performed on the QuantStudio RealTime PCR System (Invitrogen) using TaqMan probes for CB1 (CnR1-Rn02758689_s1) and CB2 (CnR2-Rn00571953_m1) receptors, $\beta$-actin (actb-Rn00667869_m1), and mitogen-activated protein kinase 6 (mapk6-Rn00581152_m1). Data were collected using QuantStudio 12K Flex Software version 1.0 (Applied Biosystems). All analysis settings were set to default. All samples generated $C_{t}$ values within an acceptable linear range (between 15 and 30 cycles). Both actb and mapk6 were highly stable between all 10 samples with variance within $1 \mathrm{C}_{\mathrm{t}}$. The $\mathrm{SD}$ between replicates was very low with the highest being 0.1 .

Chemicals. NBQX, DL-AP5, TTX, and CFA were purchased from Sigma. DERM-A594 was a generous gift from Dr. Seksiri Arttamangkul and Dr. John Williams (Vollum Institute, Oregon Health \& Science University). WIN55212, rimonabant (SR141716), N-cyclohexylcarbamic acid 3'-(aminocarbonyl)[1,1'-biphenyl]-3-yl ester (URB597), AM1241, GW405833, AM630, and SR144528 were purchased from Abcam. All chemicals were dissolved according to the manufacturer's instructions and made in stock solution kept in $-20^{\circ} \mathrm{C}$, then diluted to final concentration into aCSF on the day of the experiment. Stock solutions of cannabinoids were prepared in DMSO and diluted using aCSF to a final concentration of $0.03 \%-0.1 \%$ DMSO and $0.05 \%$ BSA to decrease ad- sorption to the perfusion system. We tested several concentrations of each cannabinoid agonist and antagonist to determine the concentration range for in vitro slice experiments. The lipophilicity of the drugs necessitates using higher concentrations than determined in cell culture experiments (Vaughan et al., 1999).

Data analyses. All data are reported as mean \pm SEM. Unpaired or paired Student's $t$ test or Mann-Whitney $U$ test was used in two-group comparisons where appropriate. One- or two-way ANOVA followed by Dunnett's or Sidak multiple-comparisons test was used for comparisons with more than two groups where appropriate to determine statistical significance. The criterion for significance was set at ${ }^{*} p<0.05$ or ${ }^{* *} p<$ 0.001 (GraphPad Prism 6).

\section{Results}

GABA release is enhanced in RVM neurons following persistent inflammation

Whole-cell patch-clamp recordings were performed in DERMA594-labeled and unlabeled RVM neurons from naive and CFAtreated rats 5-7 d after CFA injections. Spontaneous mIPSC frequency was increased when recording from RVM neurons from CFA-treated compared with naive rats (Fig. 1). The mIPSC frequency was increased in both DERM-A594-labeled and unlabeled RVM neurons to similar extents (two-way ANOVA, cell type, $F_{(1,34)}=2.28, p=0.14$ ), and there were no changes in mean mIPSC amplitude distributions. In addition, no significant differences were noted in mean rise time and decay time of the 
A

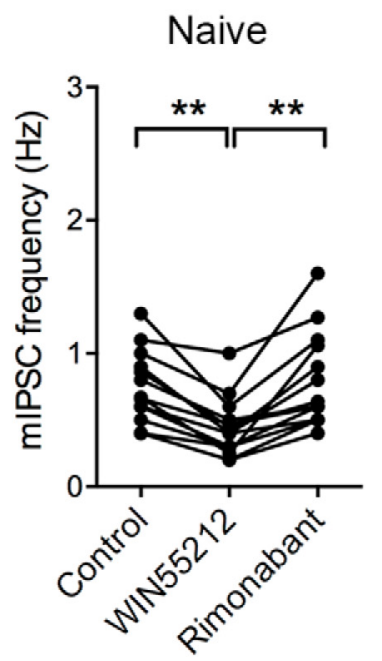

C

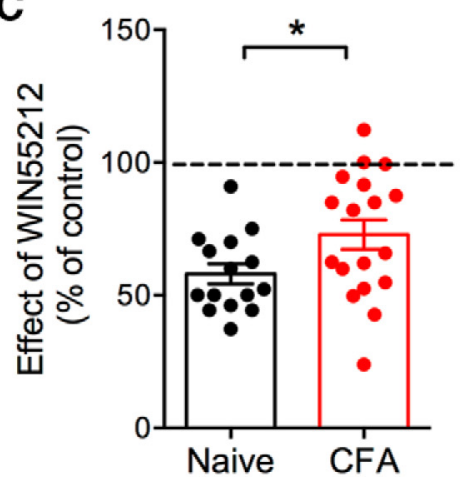

B

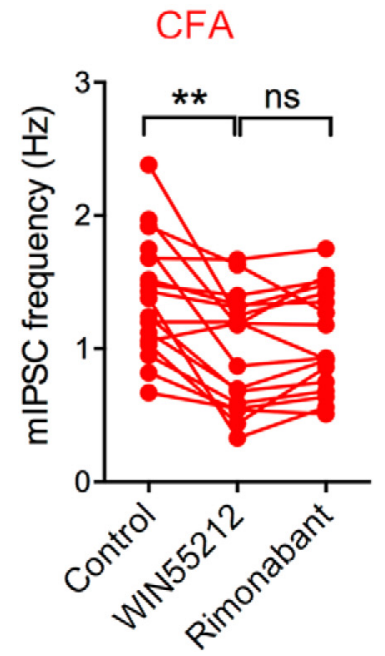

D

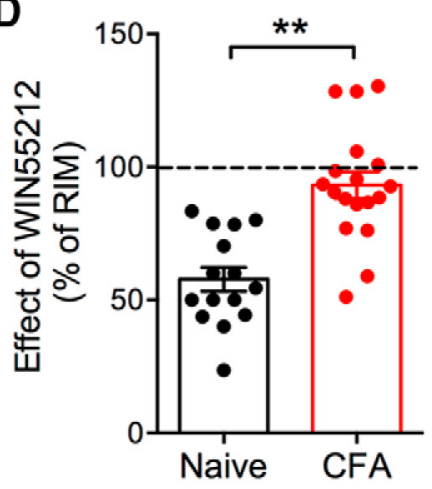

Figure 5. CB1 receptor function is reduced in RVM neurons from CFA-treated rats. $A, B$, Summary data showing the change in mIPSC frequency in the presence of WIN55212 and after addition of the CB1 receptor antagonist rimonabant in RVM neurons from naive and CFA-treated rats (tw0-way repeated-measures ANOVA, interaction, $F_{(4,60)}=5.27, p=0.001$; Sidak's multiple comparisons test). ${ }^{* *} p<0.01$. Rimonabant reversed WIN55212 inhibition of mIPSC frequency in RVM neurons from naive but not in CFA-treated rats. $C$, The effect of WIN55212 was greater in slices from naive rats (unpaired $t$ test, $t_{(31)}=2.12$, normalized to control mIPSC frequencies). ${ }^{*} p=0.04$. D , The effect of WIN55212 was also greater in slices from naive rats (unpaired $t$ test, $t_{(31)}=5.15$, normalized to mIPSC frequencies in the presence of rimonabant). ${ }^{* *} p<0.0001$.
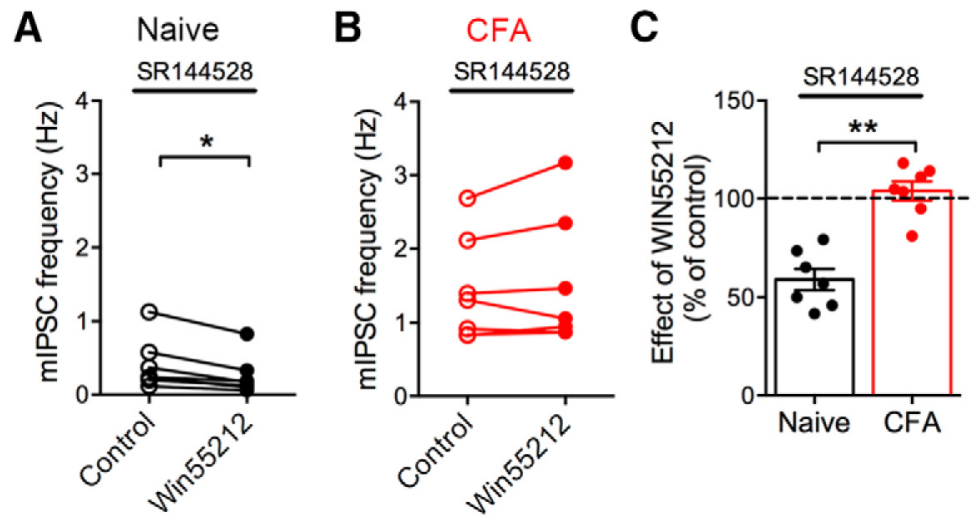

Figure 6. The selective CB2 antagonist SR144528 blocks WIN55212 effects in CFA-treated but not naive rats. $\boldsymbol{A}$, WIN55212 reduces mIPSC frequency in naive RVM neurons in the presence of the CB2 antagonist SR144528 (3 $\mu \mathrm{m})$ (Wilcoxon matched-pairs signed rank test, $W=-28$ ). ${ }^{*} p=0.02$. $B$, WIN55212 did not inhibit mIPSC frequency in CFA-treated rats in the presence of SR144528 (Wilcoxon matched-pairs signed rank test, $\mathrm{W}=12$ ). $p=0.38$. C, The effect of WIN55212 in the presence of CB2 antagonist SR144528 was greater in RVM neurons from naive compared with CFAtreated rats (unpaired $t$ test, $t_{(12)}=6.26$ ). ${ }^{* *} p<0.0001$. Data are normalized to mIPSC frequency in the presence of SR144528.

mIPSCs (data not shown). The change in frequency without a significant change in the mIPSC amplitude or kinetics is consistent with a presynaptic change in GABA release in RVM caused by persistent inflammation.

\section{Endocannabinoid activation of CB1 receptors in RVM neurons is reduced following persistent inflammation}

There is evidence that endocannabinoids tonically inhibit GABA release in adult RVM neurons (Li et al., 2015). We tested the hypothesis that the enhanced GABA release in CFA-treated RVM slices is due to a reduction in endocannabinoid modulation of GABA release by CB1 receptors during persistent inflammation. The selective CB1 receptor antagonist rimonabant (also called SR141716, $5 \mu \mathrm{M}$ ) was used to detect the degree of tonic inhibition in the RVM. We previously observed that rimonabant inhibited GABA release similarly onto DERM-A594-labeled and unlabeled RVM neurons under control conditions (Li et al., 2015), and there were no differences in mIPSC frequency between the two cell types in CFA-treated animals (Fig. 1), so the data were combined for the remainder of the experiments. Rimonabant increased mIPSC frequency in RVM slices from naive animals (Fig. $2 A, C$ ). However, this effect was absent in CFA-treated animals (Fig. $2 B, C)$. We did not observe differences in the effects of rimonabant on mIPSC amplitudes (Fig. 2D). These data indicate that tonic activation of $\mathrm{CB} 1$ receptors does not inhibit GABA release in the RVM during persistent inflammation.

To determine whether bioavailability of endocannabinoids is altered by persistent inflammation, a mass spectrophotometry lipidomics analysis was used to examine the levels of 2-AG and AEA using quantitative LC-MS/MS. There were no significant differences in 2-AG levels in RVM tissue between naive $(2.9 \pm 0.4$ $\mathrm{ng} / \mathrm{mg}$ wet weight, tissue from 11 rats) and CFA-treated animals $(2.6 \pm 0.3 \mathrm{ng} / \mathrm{mg}$ wet weight, tissue from 8 rats; $t_{(17)}=0.46$, $p=0.65)$. Similarly, AEA levels did not differ in the RVM between naive (1.2 \pm $0.2 \mathrm{pg} / \mathrm{mg}$ wet weight, $n=11 \mathrm{rats})$ and CFA-treated animals $(1.1 \pm 0.1 \mathrm{pg} / \mathrm{mg}$ wet weight, $n=8$ rats; $t_{(17)}=0.41$, $p=0.69)$.

The fatty-acid amide hydrolase (FAAH) inhibitor URB597 (McKinney and Cravatt, 2005) was used to examine whether the hydrolysis of endocannabinoids is enhanced in persistent inflammation. In RVM slices from naive animals, 
URB597 $(1 \mu \mathrm{M})$ promoted inhibition of GABAergic mIPSCs (Fig. 3A) but did not alter mIPSC amplitude (Fig. 3B). The degree of URB597 inhibition of mIPSC frequency was reduced in CFA-treated animals (Fig. 3C), again without affecting mIPSC amplitude (Fig. 3D). The inhibition in MIPSC frequency by URB597 was significantly different in naive slices compared with CFA-treated slices (Fig. 3E) without affecting mIPSC amplitude distributions (Fig. 3F). There were also no differences in mean rise time and decay time constant from naive and CFA rat RVM (data not shown). Thus, endocannabinoids hydrolyzed by FAAH are active in the RVM of naive rats but have substantially reduced effects in the RVM of CFAtreated rats. These data further indicate that increased FAAH activity does not underlie the changes in endocannabinoid modulation of GABA release in persistent inflammatory pain.

\section{$\mathrm{CB} 1$ receptor function is reduced, but} CB2-mediated inhibition of GABA release is increased in the RVM in persistent inflammation

We next determined whether levels of $\mathrm{CB} 1$ or $\mathrm{CB} 2$ receptor $\mathrm{mRNA}$ or protein in the RVM were altered as a consequence of inflammation. Both $\mathrm{CB} 1$ and $\mathrm{CB} 2$ receptor mRNA was detected by qPCR, but there was no difference in mRNA expression of these receptors in the RVM of CFA-treated compared with naive rats (Fig. 4A, C). Western blot analysis showed a significant decrease in the level of CB1 receptor protein in the RVM of CFAtreated compared with naive rats (Fig. $4 B)$. These data, together with the lack of significant changes in endocannabinoid levels, imply that inflammatory pain decreases $\mathrm{CB} 1$ receptor expression. We did not observe changes in CB2 protein levels in the predicted size range (Fig. 4D).

To test whether reduced CB1 receptor levels in the RVM of CFA-treated rats are associated with changes in CB1 receptor function, the effects of a mixed $\mathrm{CB} 1 / \mathrm{CB} 2$ receptor agonist WIN55212-2 (WIN55212) were examined in RVM slices from naive and CFA-treated rats. Superfusion of WIN55212 (5 $\mu \mathrm{M})$ reduced $\mathrm{mIPSC}$ frequency in both naive and CFA-treated slices (Fig. 5A,B). However, the WIN55212-mediated reduction in mIPSC frequency was reversed by the selective $\mathrm{CB} 1$ receptor antagonist rimonabant $(5 \mu \mathrm{M})$ only in naive animals. This is consistent with effects of rimonabant alone (Fig. 2). The inhibition of mIPSC frequency was greater in naive compared with CFAtreated rats regardless of whether WIN55212 inhibition was measured from control or after superfusion of rimonabant (Fig. $5 C, D)$. WIN55212 and rimonabant had no effects on mIPSC amplitude (data not shown). Together, these data indicate that the function of CB1 receptors is reduced in RVM neurons during persistent inflammatory pain.

Because WIN55212 is a mixed CB1/CB2 receptor agonist, the lack of reversal of WIN55212 inhibition by rimonabant in CFA-
B

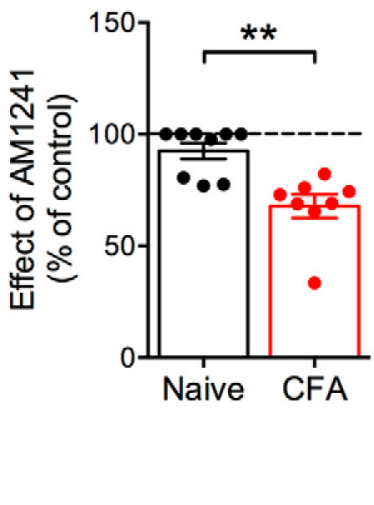

\section{D}

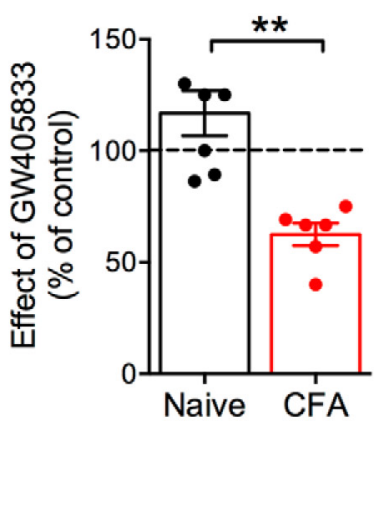

Figure 7. The selective CB2 agonists AM1241 and GW405833 inhibit GABA release in RVM neurons from CFA-treated rats. $A$, The CB2 agonist AM1241 (3 $\mu \mathrm{M})$ significantly inhibits mIPSC frequency in neurons from (FA-treated but not in naive rats (two-way repeated-measures ANOVA, interaction, $F_{(2,30)}=9.90, p=0.0005$; Dunnett's multiple comparisons test). ${ }^{*} p<0.05$. $B$, The

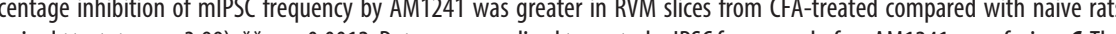
measures ANOVA, interaction, $F_{(2,22)}=14.23, p=0.0001$; Dunnett's multiple comparisons test). ${ }^{*} p<0.05$. $\boldsymbol{D}$, The percentage inhibition of mIPSC frequency by GW405833 was greater in RVM slices from CFA-treated compared with naive rats (unpaired $t$ test, $\left.t_{(11)}=4.54\right) .{ }^{* *} p=0.001$. Data are normalized to control mIPSC frequency before GW405833 superfusion.

treated rats suggested that WIN55212 activates CB2 receptors in the CFA-treated rats. To test this hypothesis, the CB2 antagonist SR144528 (3 $\mu \mathrm{M})$ was applied before WIN55212 superfusion. WIN55212 significantly inhibited mIPSC frequency in the presence of SR144528 in recordings from RVM slices of naive rats (Fig. 6A), indicating that the effects of WIN55212 were not mediated by CB2 receptors. However, WIN55212 had no effect in the presence of SR144528 in RVM slices from CFA-treated animals (Fig. 6B). WIN55212-mediated inhibition of mIPSC frequency was also significantly greater in the presence of SR 144528 in RVM neurons from naive compared with CFA-treated rats (Fig. 6C).

We tested the ability of a selective CB2 agonist AM1241 (Malan et al., 2001) to inhibit mIPSC frequency in the RVM. AM1241 $(3 \mu \mathrm{M})$ had no effect on RVM neurons from naive animals (Fig. 7A). However, AM1241 significantly reduced mIPSC frequency in RVM neurons from CFA-treated animals. The selective CB2 antagonist SR144528 reversed this effect. Inhibition by AM1241 was significantly increased in CFA-treated compared with naive animals (Fig. 7B). AM1241 did not change mIPSC amplitude in RVM neurons from naive (paired $t$ test, $t_{(8)}=1.25$, $p=0.25$ ) or CFA-treated rats (paired $t$ test, $t_{(7)}=0.066, p=$ $0.95)$. The kinetics of mIPSCs (rise time and decay constant) were 
A

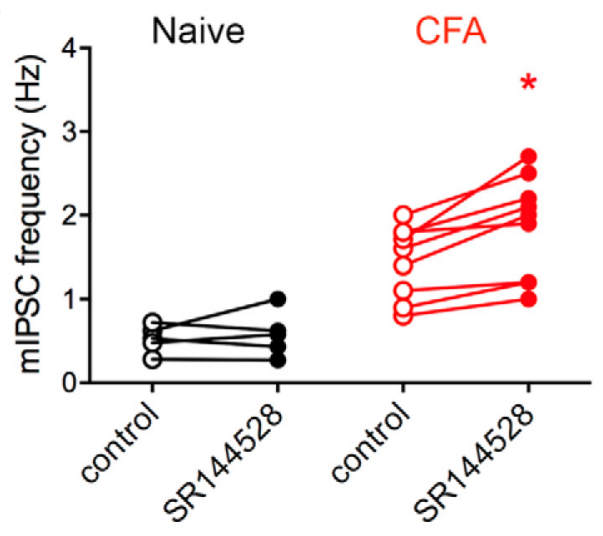

B

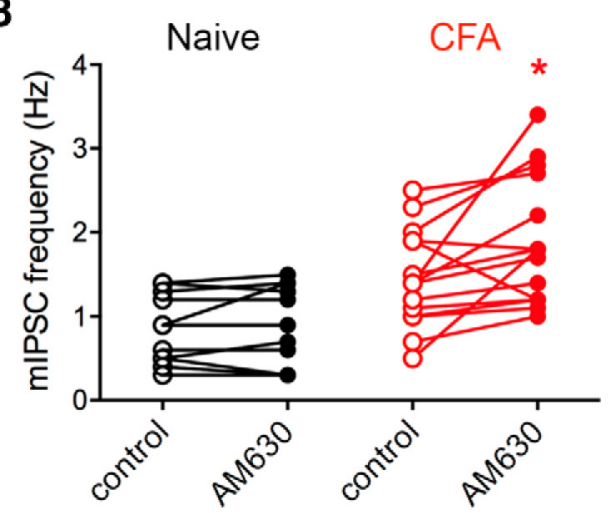

Figure 8. Endocannabinoid tone is present in the RVM of CFA-treated rats. $\boldsymbol{A}$, The CB2selective antagonist SR144528 increases mIPSC frequency in CFA-treated rats but not naive rats (two-way repeated measure ANOVA, interaction, $F_{(1,13)}=5.84, p=0.03$, Sidak's multiple comparison). ${ }^{*} p<0.05$. $\boldsymbol{B}$, The (B2-selective antagonist AM630 also increases mIPSC frequency in CFA-treated rats without an effect in naive rats (two-way repeated measure ANOVA, interaction, $F_{(1,26)}=4.28, p=0.049$, Sidak's multiple comparison). ${ }^{*} p<0.05$.

not altered by AM1241 in either group (data not shown). We observed similar results using another $\mathrm{CB} 2$ receptor-selective agonist GW405833 (1 $\mu \mathrm{M}$; Fig. 7C,D).

To further identify whether tonic activity of CB2 receptors modulate GABA release in CFA-treated RVM slices, we tested whether the CB2-selective antagonists SR144528 and AM630 had effects on presynaptic GABA release alone. In RVM slices from naive rats, SR144528 (3 $\mu \mathrm{M})$ did not alter mIPSC frequency. In contrast, SR144528 significantly increased mIPSC frequency recorded from RVM neurons in CFA-treated rats (Fig. 8A). Similar results were obtained with another selective $\mathrm{CB} 2$ antagonist AM630 where mIPSC frequencies were increased only in RVM neurons from CFA-treated rats (Fig. $8 B$ ). These data indicate there is tonic activation of $\mathrm{CB} 2$ receptors by endocannabinoids in CFA-treated rats.

\section{Discussion}

The RVM is an integral brainstem relay for the descending modulation of pain (Heinricher and Ingram, 2008). In vivo single-unit recordings have shown that RVM neurons are dynamically modulated in adult rats in the transition from acute to chronic inflammation (Cleary and Heinricher, 2013). The present studies addressed whether $\mathrm{GABA}_{\mathrm{A}}$-mediated synaptic currents and endocannabinoid inhibition of GABAergic synaptic transmission are modulated in the RVM of adult rats during persistent inflammation. We observed increased GABA release and reduced tonic inhibition by endocannabinoid activation of CB1 receptors in the RVM of CFA-treated rats. We also show evidence for an emergence of CB2 receptor actions in the RVM after persistent inflammation.

\section{Modulation of GABA release in the RVM during persistent inflammation}

GABA signaling is integral to the coordination and activation of the descending pain circuit. Opioid-induced inhibition of GABA release disinhibits PAG and RVM output neurons (Heinricher and Ingram, 2008; Lau and Vaughan, 2014) and microinjection of $\mathrm{GABA}_{\mathrm{A}}$ receptor antagonists in either area results in antinociception (Moreau and Fields, 1986; Heinricher and Tortorici, 1994; Bobeck et al., 2009). Altered GABA release in the PAG and RVM is associated with chronic inflammatory or neuropathic pain models, although both increases and decreases in GABAergic mIPSCs have been reported (Hahm et al., 2011; Zhang et al., 2011; Zhang et al., 2013) indicating the complexity of the changes in the descending pain circuit. One key variable in these studies may be age of animals that are used for recording as we have previously reported a marked decrease in GABA release probability between neonatal and adult RVM neurons that is the result of increased endocannabinoid tone in the adult rat RVM (Li et al., 2015). Other laboratories have also observed important differences in the function of the RVM between neonatal and adult rats (Hathway et al., 2009, 2012). We focused our studies on adult rats to understand modulation of endocannabinoid signaling in the RVM during persistent inflammation.

\section{Cannabinoid modulation of the descending pain pathway}

Cannabinoid-mediated antinociception involves brainstem circuitry similar to that mediating opioid analgesia (Meng et al., 1998; Meng and Johansen, 2004). Indeed, cannabinoids inhibit GABA release in the PAG and RVM, as do opioids (Vaughan et al., 1999, 2000). Antinociception mediated by systemic administration of the nonselective CB1 and CB2 agonist WIN55212 is blocked by inactivation of the RVM with the $\mathrm{GABA}_{\mathrm{A}}$ receptor agonist muscimol, indicating that the RVM contributes to the analgesic effects of cannabinoids (Meng et al., 1998). Further, WIN55212 modulates RVM ON and OFF cells similarly to opioids (Meng and Johansen, 2004), supporting the idea that cannabinoid activation of the descending pain pathway occurs via a mechanism similar to opioids. The present studies show that the CB1-selective antagonist rimonabant increased GABAergic mIPSCs onto both putative ON (DERM-A594-labeled) and OFF (unlabeled) RVM neurons providing evidence for a tonic cannabinoid-mediated inhibition of GABA terminals in adult RVM. This is consistent with a previous report that both RVM $\mathrm{ON}$ - and OFF-cell firing activity were modulated following systemic administration of a CB1 receptor antagonist during in vivo microelectrode recordings (Meng et al., 1998). However, inhibition of GABA release would be expected to increase firing of both cell types, but ON cells exhibit reduced activity in the presence of cannabinoid agonists (Meng et al., 1998; Meng and Johansen, 2004). Cannabinoid agonists produce their effects via presynaptic actions (Vaughan et al., 1999; Atwood et al., 2012), so a direct postsynaptic effect of cannabinoid agonists on RVM ON cells is not likely. A more plausible explanation is that there are CB1 receptors on glutamatergic afferents to RVM ON cells or changes in other neurons within the descending pain circuit. Glutamate receptor activation is required for the RVM ON-cell burst in response to a nociceptive stimulus (Heinricher and Roychowdhury, 1997; Heinricher and McGaraughty, 1998), and cannabi- 
noid agonists also inhibit glutamate release in the PAG (Vaughan and Christie, 2000). Future experiments will test the role of cannabinoid modulation of glutamatergic inputs in the adult RVM.

\section{Loss of $\mathrm{CB} 1$ receptor function during persistent inflammation}

The present studies provide evidence that $\mathrm{CB} 1$ receptors are downregulated during persistent inflammation. In naive rats, superfusion of the selective $\mathrm{CB} 1$ antagonist rimonabant significantly increased GABAergic mIPSC frequency. However, in CFA-treated rats, rimonabant had a reduced effect on mIPSC frequency. In addition, lower CB1 receptor levels were detected by Western blot analysis, suggesting that $\mathrm{CB} 1$ receptors are downregulated in the adult rat RVM during persistent inflammation. Our data are consistent with the loss of CB1 receptor function and protein levels in the PAG following chronic constriction injury (CCI), a neuropathic pain model (Palazzo et al., 2012). Other groups have reported desensitized and/or reduced CB1 levels following sustained or repeated cannabinoid administration (Sim et al., 1996; Breivogel et al., 1999; Dudok et al., 2015). Given that it has been reported that both AEA and 2-AG levels are significantly increased in the RVM 3-7 d after CCI (Petrosino et al., 2007), we hypothesized that reduced CB1 receptor function was the result of increased bioavailability of endocannabinoids and desensitization or downregulation of CB1 receptors. However, we did not observe changes in AEA or 2-AG levels in the RVM of CFA-treated animals compared with naive rats. Therefore, the mechanism underlying the loss of $\mathrm{CB} 1$ receptor levels and function following persistent inflammation remains to be elucidated. The difference in results from this study using a model of persistent inflammation and the previous study using CCI (Petrosino et al., 2007) indicates that endocannabinoid regulation in the RVM may be different depending on the chronic pain model. Nonetheless, CB1 receptor function is compromised in both CCI and persistent inflammation.

\section{Emergence of CB2 receptor actions in RVM during persistent inflammation}

Early reports characterizing the $\mathrm{CB}$ receptor system indicated that $\mathrm{CB} 1$ receptors are localized to the CNS and that $\mathrm{CB} 2$ receptors are localized to peripheral tissues, including the immune system and bone. More recently, numerous functional and anatomical evidence suggests that $\mathrm{CB} 2$ receptors are expressed in the nervous system (for review, see Atwood and Mackie, 2010). Both receptors are implicated in analgesic actions of cannabinoids (Malan et al., 2001; Jayamanne et al., 2006; Anderson et al., 2014), and CB2 receptors are dramatically upregulated in the spinal cord and periphery in inflammatory (Beltramo et al., 2006; Burston et al., 2013) and neuropathic (Ibrahim et al., 2003; Zhang et al., 2003; Sagar et al., 2005; Guindon and Hohmann, 2008) pain models. CB2 receptors also play an important role in inhibiting chemotherapy-induced neuropathic pain (Rahn et al., 2008; Deng et al., 2015a). We observed functional effects of selective $\mathrm{CB} 2$ agonists and antagonists in the RVM of CFA-treated rats that were not present in RVM recordings from naive rats. These data suggest that CB2 receptors are upregulated or may be trafficked to the plasma membrane of RVM neurons in persistent inflammation. We did not find an increase in $\mathrm{CB} 2 \mathrm{mRNA}$ in the RVM in CFA-treated rats (although CB2 receptor mRNA was detected in the RVM) or an increase in CB2 protein levels using Western blot analysis. However, both mRNA and protein levels were low in RVM due to the low expression levels of CB2 receptors and poor specificity of detection methods (Marchalant et al.,
2014; Li and Kim, 2015). The lack of changes in mRNA expression of both $\mathrm{CB} 1$ and $\mathrm{CB} 2$ receptors is consistent with the functional data showing effects of both receptors on presynaptic GABA release. Presynaptic receptors are probably expressed in neurons outside of the RVM and trafficked to terminals projecting into the RVM.

An alternative hypothesis is that the emergence of $\mathrm{CB} 2$ receptor function may be a result of CB2 receptors expressed on microglia and other cells in the immune system (Stella, 2010). CB2 modulation of microglial activity has been observed in the periphery (Romero-Sandoval and Eisenach, 2007; RomeroSandoval et al., 2008), as well as in the CNS (Racz et al., 2008; Luongo et al., 2010). Future studies will test the role of microglial activation in the CB2-mediated actions in adult RVM to determine whether inhibition is mediated by direct effects of $\mathrm{CB} 2$ receptors on presynaptic release or indirect modulation of release via neural-immune interactions.

\section{Implications for pain modulation}

The psychoactive ingredients of Cannabis and synthetic cannabinoid receptor agonists have analgesic activity in animal models of acute and chronic pain (Mackie, 2006), as well as in humans (Rukwied et al., 2003; Holdcroft et al., 2006; Ashton and Milligan, 2008). Altered descending control from the RVM has been implicated in chronic pain states (De Felice et al., 2011; Cleary and Heinricher, 2013). Importantly, our results showing increased function of $\mathrm{CB} 2$ receptor modulation of GABA signaling in CFA-treated RVM neurons suggest that selective activation of CB2 receptors may have therapeutic potential for treating persistent inflammatory pain. An additional benefit is that $\mathrm{CB} 2$ receptor agonists have a lower propensity than $\mathrm{CB} 1$ receptor agonists to induce tolerance and withdrawal effects (Deng et al., 2015b) and psychotropic side effects (Mackie, 2006; Atwood and Mackie, 2010; Parsons and Hurd, 2015).

\section{References}

Anderson WB, Gould MJ, Torres RD, Mitchell VA, Vaughan CW (2014) Actions of the dual FAAH/MAGL inhibitor JZL195 in a murine inflammatory pain model. Neuropharmacology 81:224-230. CrossRef Medline Arttamangkul S, Torrecilla M, Kobayashi K, Okano H, Williams JT (2006) Separation of mu-opioid receptor desensitization and internalization: endogenous receptors in primary neuronal cultures. J Neurosci 26:4118 4125. CrossRef Medline

Ashton JC, Milligan ED (2008) Cannabinoids for the treatment of neuropathic pain: clinical evidence. Curr Opin Investig Drugs 9:65-75. Medline

Atwood BK, Mackie K (2010) CB2: a cannabinoid receptor with an identity crisis. Br J Pharmacol 160:467-479. CrossRef Medline

Atwood BK, Straiker A, Mackie K (2012) CB(2) cannabinoid receptors inhibit synaptic transmission when expressed in cultured autaptic neurons. Neuropharmacology 63:514-523. CrossRef Medline

Beltramo M, Bernardini N, Bertorelli R, Campanella M, Nicolussi E, Fredduzzi S, Reggiani A (2006) CB2 receptor-mediated antihyperalgesia: possible direct involvement of neural mechanisms. Eur J Neurosci 23: 1530-1538. CrossRef Medline

Bobeck EN, McNeal AL, Morgan MM (2009) Drug dependent sexdifferences in periaqueducatal gray mediated antinociception in the rat. Pain 147:210-216. CrossRef Medline

Breivogel CS, Childers SR, Deadwyler SA, Hampson RE, Vogt LJ, Sim-Selley LJ (1999) Chronic delta9-tetrahydrocannabinol treatment produces a time-dependent loss of cannabinoid receptors and cannabinoid receptoractivated $G$ proteins in rat brain. J Neurochem 73:2447-2459. CrossRef Medline

Burgess SE, Gardell LR, Ossipov MH, Malan TP Jr, Vanderah TW, Lai J, Porreca F (2002) Time-dependent descending facilitation from the rostral ventromedial medulla maintains, but does not initiate, neuropathic pain. J Neurosci 22:5129-5136. Medline 
Burston JJ, Sagar DR, Shao P, Bai M, King E, Brailsford L, Turner JM, Hathway GJ, Bennett AJ, Walsh DA, Kendall DA, Lichtman A, Chapman V (2013) Cannabinoid CB2 receptors regulate central sensitization and pain responses associated with osteoarthritis of the knee joint. PLoS One 8:e80440. CrossRef Medline

Calignano A, La Rana G, Giuffrida A, Piomelli D (1998) Control of pain initiation by endogenous cannabinoids. Nature 394:277-281. CrossRef Medline

Chen J, Paudel KS, Derbenev AV, Smith BN, Stinchcomb AL (2009) Simultaneous quantification of anandamide and other endocannabinoids in dorsal vagal complex of rat brainstem by LC-MS. Chromatographia 69: 1-7. CrossRef Medline

Cleary DR, Heinricher MM (2013) Adaptations in responsiveness of brainstem pain-modulating neurons in acute compared with chronic inflammation. Pain 154:845-855. CrossRef Medline

De Felice M, Sanoja R, Wang R, Vera-Portocarrero L, Oyarzo J, King T, Ossipov MH, Vanderah TW, Lai J, Dussor GO, Fields HL, Price TJ, Porreca $F$ (2011) Engagement of descending inhibition from the rostral ventromedial medulla protects against chronic neuropathic pain. Pain 152:2701-2709. CrossRef Medline

Deng L, Cornett BL, Mackie K, Hohmann AG (2015a) CB1 knockout mice unveil sustained CB2-mediated antiallodynic effects of the mixed CB1/ CB2 agonist CP55940 in a mouse model of paclitaxel-induced neuropathic pain. Mol Pharmacol 88:64-74. CrossRef Medline

Deng L, Guindon J, Cornett BL, Makriyannis A, Mackie K, Hohmann AG (2015b) Chronic cannabinoid receptor 2 activation reverses paclitaxel neuropathy without tolerance or cannabinoid receptor 1-dependent withdrawal. Biol Psychiatry 77:475-487. CrossRef Medline

Dhopeshwarkar A, Mackie K (2014) CB2 Cannabinoid receptors as a therapeutic target-what does the future hold? Mol Pharmacol 86:430-437. CrossRef Medline

Dudok B, Barna L, Ledri M, Szabó SI, Szabadits E, Pintér B, Woodhams SG, Henstridge CM, Balla GY, Nyilas R, Varga C, Lee SH, Matolcsi M, Cervenak J, Kacskovics I, Watanabe M, Sagheddu C, Melis M, Pistis M, Soltesz I, et al. (2015) Cell-specific STORM super-resolution imaging reveals nanoscale organization of cannabinoid signaling. Nat Neurosci 18:75-86. Medline

Grimsey NL, Goodfellow CE, Scotter EL, Dowie MJ, Glass M, Graham ES (2008) Specific detection of CB1 receptors: cannabinoid CB1 receptor antibodies are not all created equal! J Neurosci Methods 171:78-86. CrossRef Medline

Guan Y, Terayama R, Dubner R, Ren K (2002) Plasticity in excitatory amino acid receptor-mediated descending pain modulation after inflammation. J Pharmacol Exp Ther 300:513-520. CrossRef Medline

Guan Y, Guo W, Zou SP, Dubner R, Ren K (2003) Inflammation-induced upregulation of AMPA receptor subunit expression in brain stem pain modulatory circuitry. Pain 104:401-413. CrossRef Medline

Guindon J, Hohmann AG (2008) Cannabinoid CB2 receptors: a therapeutic target for the treatment of inflammatory and neuropathic pain. Br J Pharmacol 153:319-334. CrossRef Medline

Hahm ET, Kim Y, Lee JJ, Cho YW (2011) GABAergic synaptic response and its opioidergic modulation in periaqueductal gray neurons of rats with neuropathic pain. BMC Neurosci 12:41. CrossRef Medline

Hathway GJ, Koch S, Low L, Fitzgerald M (2009) The changing balance of brainstem-spinal cord modulation of pain processing over the first weeks of rat postnatal life. J Physiol 587:2927-2935. CrossRef Medline

Hathway GJ, Vega-Avelaira D, Fitzgerald M (2012) A critical period in the supraspinal control of pain: opioid-dependent changes in brainstem rostroventral medulla function in preadolescence. Pain 153:775-783. CrossRef Medline

Havelin J, Imbert I, Cormier J, Allen J, Porreca F, King T (2016) Central sensitization and neuropathic features of ongoing pain in a rat model of advanced osteoarthritis. J Pain 17:374-382. CrossRef Medline

Heinricher MM, Ingram SL (2008) The brainstem and nociceptive modulation. In: The senses, a comprehensive reference: pain, Vol 5 (Bushnell MC, Basbaum AI, eds), pp 593-626. San Diego: Academic.

Heinricher MM, McGaraughty S (1998) Analysis of excitatory amino acid transmission within the rostral ventromedial medulla: implications for circuitry. Pain 75:247-255. CrossRef Medline

Heinricher MM, Roychowdhury SM (1997) Reflex-related activation of putative pain facilitating neurons in rostral ventromedial medulla re- quires excitatory amino acid transmission. Neuroscience 78:1159-1165. CrossRef Medline

Heinricher MM, Tortorici V (1994) Interference with GABA transmission in the rostral ventromedial medulla: disinhibition of off cells as a central mechanism in nociceptive modulation. Neuroscience 63:533-546. CrossRef Medline

Heinricher MM, Tavares I, Leith JL, Lumb BM (2009) Descending control of nociception: specificity, recruitment and plasticity. Brain Res Rev 60: 214-225. CrossRef Medline

Holdcroft A, Maze M, Doré C, Tebbs S, Thompson S (2006) A multicenter dose-escalation study of the analgesic and adverse effects of an oral cannabis extract (Cannador) for postoperative pain management. Anesthesiology 104:1040-1046. CrossRef Medline

Hurley RW, Hammond DL (2000) The analgesic effects of supraspinal mu and delta opioid receptor agonists are potentiated during persistent inflammation. J Neurosci 20:1249-1259. Medline

Hurley RW, Hammond DL (2001) Contribution of endogenous enkephalins to the enhanced analgesic effects of supraspinal $\mu$ opioid receptor agonists after inflammatory injury. J Neurosci 21:2536-2545. Medline

Iadarola MJ, Brady LS, Draisci G, Dubner R (1988) Enhancement of dynorphin gene expression in spinal cord following experimental inflammation: stimulus specificity, behavioral parameters and opioid receptor binding. Pain 35:313-326. CrossRef Medline

Ibrahim MM, Deng H, Zvonok A, Cockayne DA, Kwan J, Mata HP, Vanderah TW, Lai J, Porreca F, Makriyannis A, Malan TP Jr (2003) Activation of CB2 cannabinoid receptors by AM1241 inhibits experimental neuropathic pain: pain inhibition by receptors not present in the CNS. Proc Natl Acad Sci U S A 100:10529-10533. CrossRef Medline

Jayamanne A, Greenwood R, Mitchell VA, Aslan S, Piomelli D, Vaughan CW (2006) Actions of the FAAH inhibitor URB597 in neuropathic and inflammatory chronic pain models. Br J Pharmacol 147:281-288. CrossRef Medline

Johannes CB, Le TK, Zhou X, Johnston JA, Dworkin RH (2010) The prevalence of chronic pain in United States adults: results of an Internet-based survey. J Pain 11:1230-1239. CrossRef Medline

Kreitzer AC, Regehr WG (2002) Retrograde signaling by endocannabinoids. Curr Opin Neurobiol 12:324-330. CrossRef Medline

Lau BK, Vaughan CW (2014) Descending modulation of pain: the GABA disinhibition hypothesis of analgesia. Curr Opin Neurobiol 29:159-164. CrossRef Medline

Li MH, Suchland KL, Ingram SL (2015) GABAergic transmission and enhanced modulation by opioids and endocannabinoids in adult rat rostral ventromedial medulla. J Physiol 593:217-230. CrossRef Medline

Li Y, Kim J (2015) Neuronal expression of CB2 cannabinoid receptor mRNAs in the mouse hippocampus. Neuroscience 311:253-267. CrossRef Medline

Luongo L, Palazzo E, Tambaro S, Giordano C, Gatta L, Scafuro MA, Rossi FS, Lazzari P, Pani L, de Novellis V, Malcangio M, Maione S (2010) 1$\left(2^{\prime}, 4^{\prime}\right.$-dichlorophenyl)-6-methyl- $N$-cyclohexylamine-1,4-dihydroindeno [1,2-c]pyraz ole-3-carboxamide, a novel CB2 agonist, alleviates neuropathic pain through functional microglial changes in mice. Neurobiol Dis 37:177-185. CrossRef Medline

Mackie K (2006) Cannabinoid receptors as therapeutic targets. Annu Rev Pharmacol Toxicol 46:101-122. CrossRef Medline

Malan TP Jr, Ibrahim MM, Deng H, Liu Q, Mata HP, Vanderah T, Porreca F, Makriyannis A (2001) CB2 cannabinoid receptor-mediated peripheral antinociception. Pain 93:239-245. CrossRef Medline

Marchalant Y, Brownjohn PW, Bonnet A, Kleffmann T, Ashton JC (2014) Validating antibodies to the cannabinoid CB2 receptor: antibody sensitivity is not evidence of antibody specificity. J Histochem Cytochem 62: 395-404. CrossRef Medline

McKinney MK, Cravatt BF (2005) Structure and function of fatty acid amide hydrolase. Annu Rev Biochem 74:411-432. CrossRef Medline

Meng ID, Johansen JP (2004) Antinociception and modulation of rostral ventromedial medulla neuronal activity by local microinfusion of a cannabinoid receptor agonist. Neuroscience 124:685-693. CrossRef Medline

Meng ID, Manning BH, Martin WJ, Fields HL (1998) An analgesia circuit activated by cannabinoids. Nature 395:381-383. CrossRef Medline

Moreau JL, Fields HL (1986) Evidence for GABA involvement in midbrain control of medullary neurons that modulate nociceptive transmission. Brain Res 397:37-46. CrossRef Medline

Palazzo E, Luongo L, Bellini G, Guida F, Marabese I, Boccella S, Rossi F, 
Maione S, de Novellis V (2012) Changes in cannabinoid receptor subtype 1 activity and interaction with metabotropic glutamate subtype 5 receptors in the periaqueductal gray-rostral ventromedial medulla pathway in a rodent neuropathic pain model. CNS Neurol Disord Drug Targets 11:148-161. CrossRef Medline

Parsons LH, Hurd YL (2015) Endocannabinoid signalling in reward and addiction. Nat Rev Neurosci 16:579-594. CrossRef Medline

Petrosino S, Palazzo E, de Novellis V, Bisogno T, Rossi F, Maione S, Di Marzo V (2007) Changes in spinal and supraspinal endocannabinoid levels in neuropathic rats. Neuropharmacology 52:415-422. CrossRef Medline

Phillips RS, Cleary DR, Nalwalk JW, Arttamangkul S, Hough LB, Heinricher MM (2012) Pain-facilitating medullary neurons contribute to opioidinduced respiratory depression. J Neurophysiol 108:2393-2404. CrossRef Medline

Racz I, Nadal X, Alferink J, Baños JE, Rehnelt J, Martín M, Pintado B, Gutierrez-Adan A, Sanguino E, Manzanares J, Zimmer A, Maldonado R (2008) Crucial role of $\mathrm{CB}(2)$ cannabinoid receptor in the regulation of central immune responses during neuropathic pain. J Neurosci 28: 12125-12135. CrossRef Medline

Rahn EJ, Zvonok AM, Thakur GA, Khanolkar AD, Makriyannis A, Hohmann AG (2008) Selective activation of cannabinoid CB2 receptors suppresses neuropathic nociception induced by treatment with the chemotherapeutic agent paclitaxel in rats. J Pharmacol Exp Ther 327:584-591. CrossRef Medline

Ren K, Dubner R (2002) Descending modulation in persistent pain: an update. Pain 100:1-6. CrossRef Medline

Richardson D, Ortori CA, Chapman V, Kendall DA, Barrett DA (2007) Quantitative profiling of endocannabinoids and related compounds in rat brain using liquid chromatography-tandem electrospray ionization mass spectrometry. Anal Biochem 360:216-226. CrossRef Medline

Richardson JD, Aanonsen L, Hargreaves KM (1997) SR 141716A, a cannabinoid receptor antagonist, produces hyperalgesia in untreated mice. Eur J Pharmacol 319:R3-R4. CrossRef Medline

Romero-Sandoval A, Eisenach JC (2007) Spinal cannabinoid receptor type 2 activation reduces hypersensitivity and spinal cord glial activation after paw incision. Anesthesiology 106:787-794. CrossRef Medline

Romero-Sandoval EA, Horvath RJ, DeLeo JA (2008) Neuroimmune interactions and pain: focus on glial-modulating targets. Curr Opin Investig Drugs 9:726-734. Medline

Rukwied R, Watkinson A, McGlone F, Dvorak M (2003) Cannabinoid agonists attenuate capsaicin-induced responses in human skin. Pain 102: 283-288. CrossRef Medline

Sagar DR, Kelly S, Millns PJ, O'Shaughnessey CT, Kendall DA, Chapman V (2005) Inhibitory effects of CB1 and CB2 receptor agonists on responses of DRG neurons and dorsal horn neurons in neuropathic rats. Eur J Neurosci 22:371-379. CrossRef Medline

Sim LJ, Hampson RE, Deadwyler SA, Childers SR (1996) Effects of chronic treatment with $\delta 9$-tetrahydrocannabinol on cannabinoid-stimulated [35S]GTPgammaS autoradiography in rat brain. J Neurosci 16:80578066. Medline
Stella N (2010) Cannabinoid and cannabinoid-like receptors in microglia, astrocytes, and astrocytomas. Glia 58:1017-1030. CrossRef Medline

Ting JT, Daigle TL, Chen Q, Feng G (2014) Acute brain slice methods for adult and aging animals: application of targeted patch clamp analysis and optogenetics. Methods Mol Biol 1183:221-242. CrossRef Medline

Trang T, Al-Hasani R, Salvemini D, Salter MW, Gutstein H, Cahill CM (2015) Pain and poppies: the good, the bad, and the ugly of opioid analgesics. J Neurosci 35:13879-13888. CrossRef Medline

Vaughan CW, Christie MJ (2000) An analgesic role for cannabinoids. Med J Aust 173:270-272. Medline

Vaughan CW, Christie MJ (2005) Retrograde signalling by endocannabinoids. Handb Exp Pharmacol:367-383. Medline

Vaughan CW, McGregor IS, Christie MJ (1999) Cannabinoid receptor activation inhibits GABAergic neurotransmission in rostral ventromedial medulla neurons in vitro. Br J Pharmacol 127:935-940. CrossRef Medline

Vaughan CW, Connor M, Bagley EE, Christie MJ (2000) Actions of cannabinoids on membrane properties and synaptic transmission in rat periaqueductal gray neurons in vitro. Mol Pharmacol 57:288-295. Medline

Wilson RI, Nicoll RA (2002) Endocannabinoid signaling in the brain. Science 296:678-682. CrossRef Medline

Woodhams SG, Sagar DR, Burston JJ, Chapman V (2015) The role of the endocannabinoid system in pain. Handb Exp Pharmacol 227:119-143. CrossRef Medline

Zhang HY, Gao M, Liu QR, Bi GH, Li X, Yang HJ, Gardner EL, Wu J, Xi ZX (2014) Cannabinoid CB2 receptors modulate midbrain dopamine neuronal activity and dopamine-related behavior in mice. Proc Natl Acad Sci U S A 111:E5007-E5015. CrossRef Medline

Zhang J, Hoffert C, Vu HK, Groblewski T, Ahmad S, O'Donnell D (2003) Induction of $\mathrm{CB} 2$ receptor expression in the rat spinal cord of neuropathic but not inflammatory chronic pain models. Eur J Neurosci 17: 2750-2754. CrossRef Medline

Zhang MY, Gao Y, Btesh J, Kagan N, Kerns E, Samad TA, Chanda PK (2010) Simultaneous determination of 2-arachidonoylglycerol, 1-arachidonoylglycerol and arachidonic acid in mouse brain tissue using liquid chromatography/tandem mass spectrometry. J Mass Spectrom 45:167-177. CrossRef Medline

Zhang Z, Cai YQ, Zou F, Bie B, Pan ZZ (2011) Epigenetic suppression of GAD65 expression mediates persistent pain. Nat Med 17:1448-1455. CrossRef Medline

Zhang Z, Wang X, Wang W, Lu YG, Pan ZZ (2013) Brain-derived neurotrophic factor-mediated downregulation of brainstem $\mathrm{K}^{+}$ $\mathrm{Cl}^{-}$cotransporter and cell-type-specific GABA impairment for activation of descending pain facilitation. Mol Pharmacol 84:511-520. CrossRef Medline

Zhao S, Ting JT, Atallah HE, Qiu L, Tan J, Gloss B, Augustine GJ, Deisseroth K, Luo M, Graybiel AM, Feng G (2011) Cell type-specific channelrhodopsin-2 transgenic mice for optogenetic dissection of neural circuitry function. Nat Methods 8:745-752. CrossRef Medline 